\title{
The Proximal Element of the $\beta$ Globin Locus Control Region Is Not Functionally Required In Vivo
}

Andreas E. Kulozik, Sigrid Bail, Astrid Bellan-Koch, Claus R. Bartram, Elisabeth Kohne, and Enno Kleihauer Molecular Biology Section, Department of Pediatrics II, University of Ulm, D-7900 Ulm, Germany

\begin{abstract}
In addition to local sequence elements the regulation of the high-level, development- and tissue-specific expression of the human $\beta$ globin gene cluster appears to require distant regulatory sequences which have been termed locus control region. In the chromatin of erythroid cells the locus control region is characterized by four DNaseI hypersensitive sites that are located 6-18 kb 5 ' of the $\epsilon$ globin gene. The definition of the sequences minimally required for locus control region activity is likely to further the understanding of its physiology and will be of interest for the development of somatic gene therapy strategies of the hemoglobinopathies.

We present here the analysis of a family with a 3,030-bp deletion of sequences upstream of the $\epsilon$ globin gene including the most $3^{\prime}$ locus control region element and cosegregating $\beta^{\circ}$ thalassemia. The deletion is linked in cis to a structurally and functionally normal $\beta$ globin gene. The proximal element of the locus control region does not therefore appear to be necessary for $\beta$ globin gene activity in vivo. (J. Clin. Invest. 1991. 87: 2142-2146.) Key words: $\beta$ thalassemia $\bullet$ somatic gene therapy • DNaseI hypersensitivity • globin gene regulation • DNA deletion
\end{abstract}

\section{Introduction}

Some of the sequence elements involved in the regulation of globin gene expression are situated in close proximity to the transcription start sites. Recombinant globin genes with minimal flanking sequences have thus been shown to be expressed inducibly in transfected erythroid cell lines (1-4) and tissue and development specifically in transgenic mice (5-9). Also, retrovirally transfected bone marrow cells exhibited erythroid specific expression of the exogenous $\beta$ globin gene (10). However, the level of globin gene expression in those experiments was position dependent and generally low. It appeared therefore that additional regulatory elements are required to confer physiologic levels of globin gene expression.

Address correspondence to Andreas E. Kulozik, M.D., Ph.D., Molecular Biology Section, Dept. of Pediatrics II, Prittwitzstr. 43, D-79 Ulm, Germany.

Received for publication 12 September 1990 and in revised form 3 December 1990.

J. Clin. Invest.

(c) The American Society for Clinical Investigation, Inc. $0021-9738 / 91 / 06 / 2142 / 05 \$ 2.00$

Volume 87, June 1991, 2142-2146
The DNA flanking the $\beta$ globin gene cluster contains sequences that are arranged in the chromatin of erythroid cells to be particularly sensitive to DNaseI degradation which presumably reflects their availability to regulatory trans acting factors (11). These DNaseI hypersensitive sequences were shown to confer high level and position independent expression of a $\beta$ globin gene in transgenic mice and in transfected cell lines (12). This area has therefore been termed dominant control region (DCR) ${ }^{1}$ (12), locus activating region (LAR) (13), or locus control region (LCR) according to an agreement on the nomenclature reached at the 1990 Hemoglobin Switching Conference. The $\beta$ globin LCR contains four erythroid-specific DNaseI hypersensitive sites (termed HS 1-4) which are located in an area 6-18 kb $5^{\prime}$ of the $\epsilon$ globin gene (Figs. 1 and 2). The minimal requirements for the $\beta$ globin LCR to confer position independent, high-level, and erythroid-specific expression of recombinant globin or heterologous genes has been studied in enhancer trap assays (14), in transgenic mice $(12,15,16)$, and in transfected cell lines (17-20). Although all these experiments suggest a particularly important role of HS 2 the respective influence of the other hypersensitive sites on regulated globin gene expression is controversial. The enhancer trap and the transgenic mice assays indicate that HS 2 alone is both necessary and sufficient for conferring high-level, erythroid-specific globin gene expression. The minimal sequence requirement for this effect appears to be contained in a core of 300 (19) or even $46 \mathrm{bp}(20)$. However, $\beta$ globin genes linked to the complete LCR are more active in transgenic mice than those coupled to HS 2 only (21). The evidence obtained from transfected Friend cells also points to a more complex interaction of at least three of the four sites (22).

In vivo, the importance of the LCR for regulated globin gene expression is less well documented (Fig. 1). Two deletions encompassing much of the $\beta$ globin gene cluster including the LCR but not the $\beta$ globin gene itself (23-25) result in a thalassemic phenotype. However, these deletions are $\sim 100 \mathrm{~kb}$ large (26) and may therefore inactivate the structurally normal $\beta$ globin gene by other mechanisms than deletion of the LCR. Another deletion associated with a thalassemic phenotype removes $\sim 30 \mathrm{~kb}$ including the three most distal LCR elements (HS 2-4) and sequences upstream indicating that HS 1 alone is not sufficient for LCR activity (27).

In the family presented here, a 3,030-bp deletion of the most $3^{\prime}$ LCR element (HS 1) is demonstrated to be linked to a

1. Abbreviations used in this paper: DCR, dominant control region; HS, DNaseI hypersensitive site; LAR, locus activating region; LCR, locus control region; PCR, polymerase chain reaction; RFLP, restriction fragment length polymorphism. 


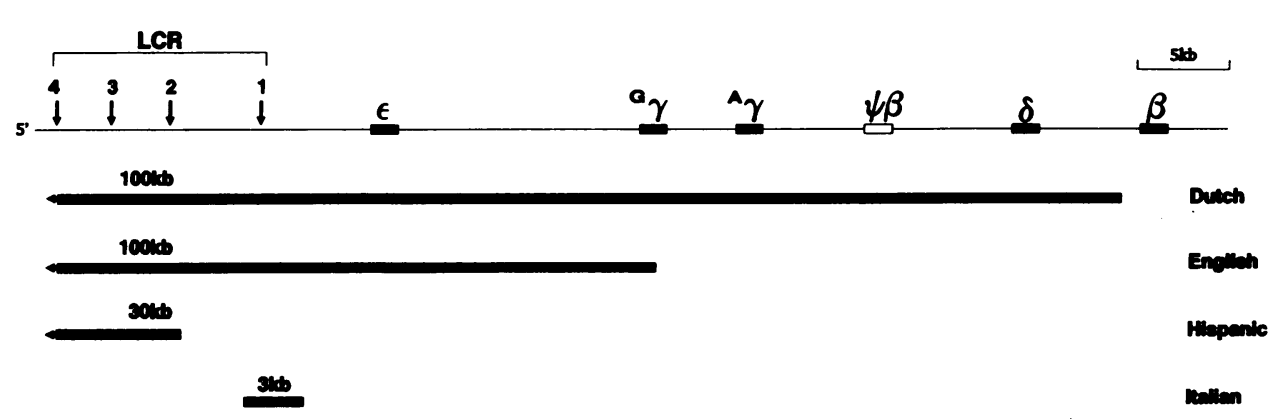

Figure 1. Deletions of the $\beta$ globin LCR that do not affect the structure of the $\beta$ globin gene. The top of the figure shows a map of the $\beta$ globin gene cluster with the DNase I hypersensitive sites, marked $1-4$. The bottom shows the extent of the Dutch, English, and Hispanic deletions of $\sim 100$ and $30 \mathrm{~kb}$ that result in a thalassemic phenotype by inactivating the $\beta$ globin gene in cis. This report describes in more detail the Italian 3-kb deletion of HS 1 that does not functionally affect the $\beta$ globin gene in cis. functional $\beta$ globin gene in cis which indicates that HS 1 is not necessary for LCR and $\beta$ globin gene activity in vivo.

\section{Methods}

Hematological analyses. These were performed using standard methods. $\mathrm{HbA}_{2}$ was measured chromatographically $(28)$ and $\mathrm{HbF}$ by alkali denaturation (29).

Restriction mapping. Restriction digests were performed with the various enzymes according to the manufacturer's recommendations (Pharmacia Fine Chemicals, Uppsala, Sweden). Southern blotting was done using standard methods (30). The filters were hybridized with ${ }^{32} \mathrm{P}$-labeled genomic fragment probes. The 5 ' probe (p1 in Figs. 2 and 3 ) was a Bgl II/Hind III fragment isolated from the recombinant 5eIII (31). The 3' probe ( $\mathrm{p} 2$ in Figs. 2 and 3) was a Bam HI/Eco RI fragment containing the genomic $\epsilon$ globin gene (32). The $\mathrm{C} \rightarrow \mathrm{T}$ mutation at position- 158 of the ${ }^{\mathrm{G}} \gamma$ globin gene was detected by Southern blot analysis of Xmn I digested genomic DNA hybridized to a $\gamma$ globin gene probe. The haplotype of DNA polymorphisms within the $\beta$ globin gene cluster ( $\beta$ haplotype) was determined according to Orkin et al. (32).

Allele-specific oligonucleotide hybridization. The mutation of the $\beta$ globin gene was determined after PCR amplification (30) of the $5^{\prime}$ portion of the $\beta$ globin gene using $24 \mathrm{mer}$ oligonucleotides (5'TATGCTTACCAAGCTGTGATTCCA; 5'-AGGGGAAAGAAAACATCAAGGGTC) as primers. The amplification products were dotted and UV cross-linked on nylon membranes and hybridized (33) to ${ }^{32}$ P-endlabeled 20 mer oligonucleotides (5'-CTCCTGAGGAGAAGTTCTGC; 5'-CTCCTGAGGGAAGTTCTGCC) spanning codon 6 and representing the normal or the $\mathrm{GAG} \rightarrow \mathrm{G}-\mathrm{G}$ mutated sequence.

DNA sequencing. The deletion breakpoint was $P C R$ amplified with primers (5'-AACACCTCTAGGCTATAAGGCAAC; 5'-ATAAGGACCAGGTATCTCAAGGCC) whose homologous sequences were known by gene mapping studies to be preserved by the deletion (Fig. 2). The amplified fragment was inserted into a pSP64 vector and sequenced by the dideoxy-nucleotide chain termination technique using sequencing primers from both sides of the polylinker (30).

\section{Results}

Hematological analyses. The two Italian index patients presented with the clinical and hematological picture of homozygous $\beta$ thalassemia intermedia. The considerable production of $\mathrm{HbF}$ is the likely reason for their relatively mild phenotype. The parents showed the typical features of heterozygous $\beta$ thalassemia minor without a hereditary persistence of fetal hemoglobin synthesis (Fig. 4).

Identification of the $\beta$ thalassemia mutation. The patients and their parents were shown by allele-specific oligonucleotide hybridization of PCR amplified $\beta$ globin gene fragments to be homozygous and heterozygous, respectively, for the codon 6 frameshift GAG $\rightarrow \mathrm{G}-\mathrm{G} \beta^{\circ}$ thalassemia mutation (not shown).

Restriction mapping. $\beta$ haplotype analysis showed linkage of the $\beta$ thalassemia mutation to haplotype IX according to Orkin et al. (32). The parents' normal $\beta$ globin genes were linked to haplotype I (Fig. 4). These two haplotypes differ at multiple sites including the Hind II RFLP $5^{\prime}$ of the $\epsilon$ globin gene. Xmn I mapping indicated the linkage of the $\beta$ thalassemia mutation with the $C \rightarrow T$ mutation at position- 158 of the ${ }^{\mathrm{G}} \boldsymbol{\gamma}$ globin gene promoter (not shown). This mutation has previously been associated with raised $\mathrm{HbF}$ levels and a mild clinical phenotype of homozygous $\beta$ thalassemia (34-36) and is

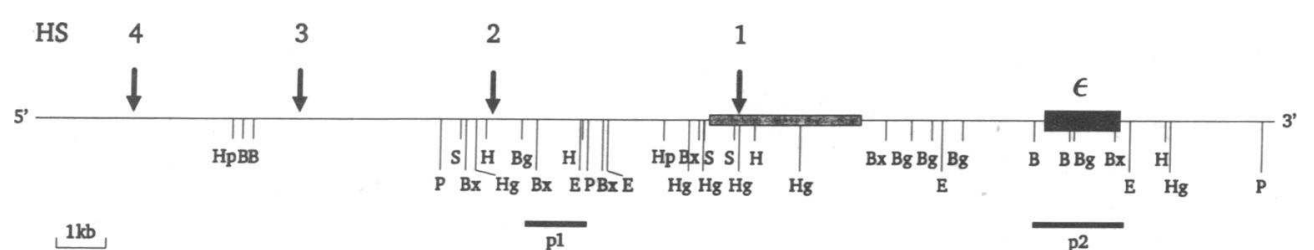
a deleted Hgi AI site and the 3' breakpoint between a further deleted Hgi AI and a preserved Bst XI site. The restriction fragment sizes detected are shown in Table I. The $\epsilon$ globin gene $(\epsilon)$ and the probes used (p1 and p2) are shown as solid bars and the deleted sequences by a stippled bar. The HS are termed according to the nomenclature agreed at the 1990 Hemoglobin Switching Conference. The relevant restriction sites are indicated by $B$ (Bam HI), $E$ (Eco RI), $H$ (Hind III), $P$ (Pst I), $S$ (Sac I), $B g$ (Bgl II), $B x$ (Bst X1), $H g$ (Hgi AI), and $H p$ (Hpa I). 


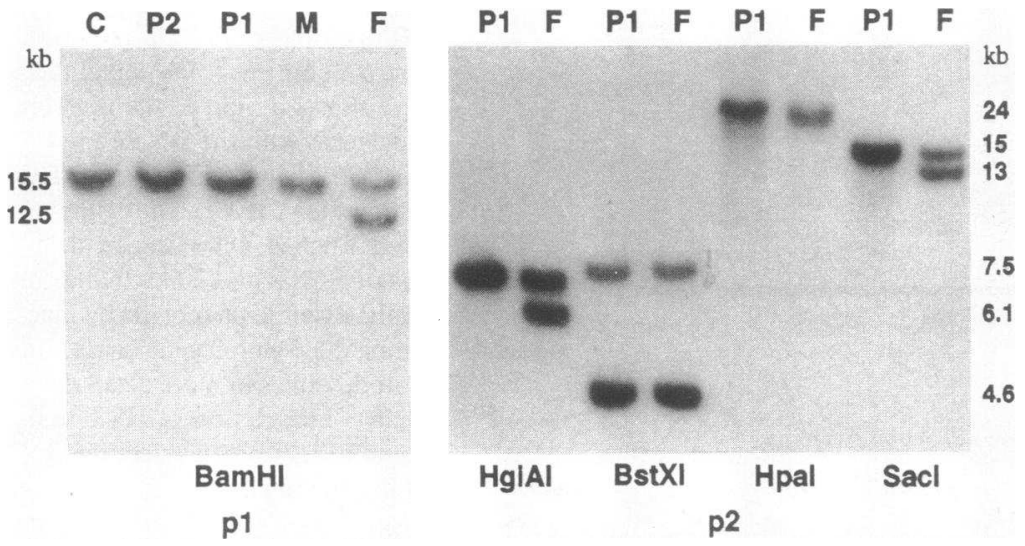

Figure 3. Autoradiographs showing Southern blots of the family members' genomic DNA ( $F$, father; $M$, mother; $P 1$, first daughter; $P 2$, second daughter) digested with the indicated restriction enzymes and hybridized to the 1.3$\mathrm{kb}$ Bam HI/Eco RI genomic $\epsilon$ globin gene probe ( $p 2$, see also Table I and Fig. 2) and to the 1.2-kb Bgl II/Hind III fragment located $10 \mathrm{~kb} 5^{\prime}$ of the $\epsilon$ globin gene ( $p l$, see also Table I and Fig. 2). likely to explain the intermediate severity of the hematological picture of the two index patients described here.

Mapping of the region upstream of the $\epsilon$ globin gene indicated a deletion between a Bst XI and a Sac I site 3.1 and $6.7 \mathrm{~kb}$ $5^{\prime}$ of the $\epsilon$ cap site on the father's chromosome which he did not inherit to either of his daughters (Table I, Figs. 1-4). The deletion was thus linked to his structurally and functionally normal $\beta$ globin gene.

PCR amplification and DNA sequencing of the deletion breakpoint region. The PCR primers were chosen on the basis of the restriction mapping data for the product to contain the preserved Bst XI and Sac I sites. Sequencing of this fragment (Fig. 5) located the $5^{\prime}$ and $3^{\prime}$ deletion breakpoints to short stretches of five thydimylate residues $3,030 \mathrm{bp}$ apart from each

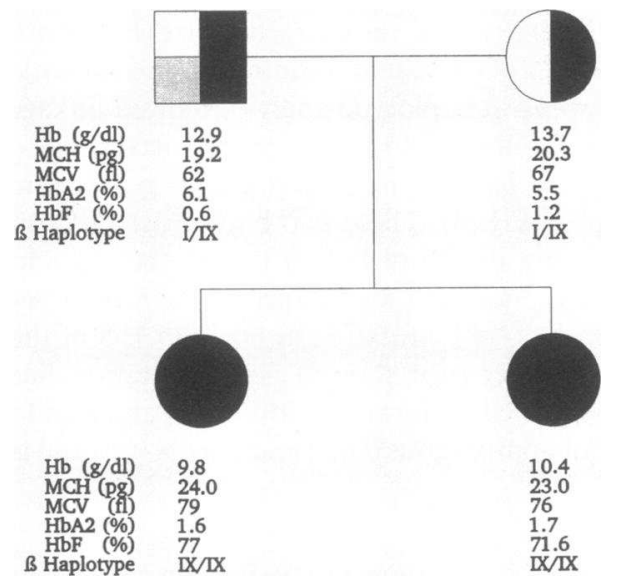

Figure 4. Phenotypic expression of the HS 1 deletion. Both index patients are homozygous for a $\beta^{\circ}$ thalassemia mutation (codon 6 GAG $\rightarrow G-G)$ and for a promoter mutation of the ${ }^{G} \gamma$ globin gene $(C \rightarrow T$ at position-158) and presented with the clinical and hematologic picture of thalassemia intermedia. These mutations were linked to a haplotype of restriction polymorphisms in the $\beta$ globin gene cluster termed \#IX according Orkin et al. (32). Both parents were healthy and showed the typical hematologic picture of heterozygous $\beta$ thalassemia. Their normal $\beta$ globin genes were linked to the $\beta$ haplotype \#I and, in the case of the father, to the 3,030-bp deletion of HS 1 (stippled). other and 3,560-6,590 bp $5^{\prime}$ of the $\epsilon$ globin gene's cap site without any further obvious homologies. This deletion thus removes the sequences to which the most $3^{\prime}$ DNase I hypersensitive site (HS 1) within the $\beta$ globin LCR has been mapped (11-13, 17, Figs. 1 and 2). The deleted DNA contains sequences that are thought to contribute to the notional enhancer like character of this region including enhancer corelike sequences, a stretch of $28 \mathrm{~T}$ residues, a stretch of consecutive pairs of alternating purin or pyrimidine bases (11), and multiple recognition sites for the erythroid-specific DNA binding protein GF-1 (37).

\section{Discussion}

The definition of the minimal requirements for the activity of the $\beta$ globin LCR is likely to contribute to the understanding of the complex mechanisms involved in globin gene regulation. The studies in transfected cell lines and in transgenic mice suggest that the chief LCR effect depends on short DNA sequences within HS 2 or HS 3 (12-22). However, the interpretation of

Table I. Restriction Mapping of the 3,030-bp HS I Deletion

\begin{tabular}{lccccc}
\hline & \multicolumn{3}{c}{$\epsilon$} & & \multicolumn{2}{c}{$5^{\prime} \epsilon$} \\
\cline { 2 - 3 } \cline { 5 - 6 } & Wildtype & Deletion & & Wildtype & Deletion \\
\hline Sac I & 15 & 13 & & 4.7 & 4.7 \\
Hpa I & 24 & 24 & & 8.6 & 8.6 \\
Bst XI & $7.7 / 4.6$ & $7.7 / 4.6$ & & $1.3 / 1.2$ & $1.3 / 1.2$ \\
Hgi AI & 7.3 & 6.1 & & $2.7 / 1.4$ & $2.7 / 1.4$ \\
Bgl II & 10.7 & 10.7 & & 7.6 & 4.5 \\
Bam HI & 12.4 & 12.4 & & 15.5 & 12.5 \\
Hind III & 8.1 & 8.3 & & 2 & 2 \\
Eco RI & 3.7 & 3.7 & & 10.4 & 10.4 \\
Pst I & 13.5 & 10.5 & & 3 & 3
\end{tabular}

Genomic digests with the indicated enzymes were Southern blotted and hybridized to a 1.3-kb Bam HI/Eco RI genomic $\epsilon$ globin gene fragment (p2 in Figs. 2 and 3) and to a 1.2-kb Bgl Il/Hind III fragment located $10 \mathrm{~kb} \mathrm{5}$ of the $\epsilon$ globin gene (p1 in Figs. 2 and 3). Restriction fragment sizes are in kilobases. 


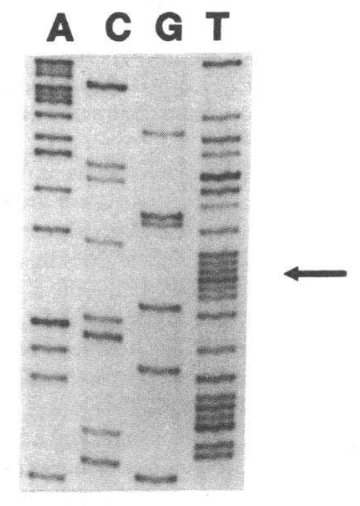

Figure 5. DNA sequence of the HS 1 3,030-bp deletion breakpoint region. The breakpoints are located in short stretches of $5 \mathrm{~T}$ residues $\begin{array}{llll}\text { 5'-N GCTTCTTTTATGATCACTGT THIT } & \text { TAATATGCTTTAAGTTCTGGGGTAC } \\ \text { Del GCTTCTTTTATGATCACTGT THIT } & \text { CATGGTATCTCATATGATAAACAAA } \\ \text { 3'-N GAAAGAAAAGCAATAATCCA THYT } & \text { CATGGTATCTCATATGATAAACAAA }\end{array}$ 6,590 and $3,560 \mathrm{bp} 5^{\prime}$ of the $\epsilon$ globin gene's cap site. There are no obvious areas of further homology and the deletion seems to be the result of an illegitimate recombination event. The arrow indicates the $5 \mathrm{~T}$ residues.

the experimental results is complicated by a number of variables which are difficult to be controlled for. Developing transgenic mice with a very high expression of exogenous globin genes may thus become thalassemic and will probably be selected against. Also, studies of transfected cell lines are unlikely to reflect all relevant levels of gene regulation. It is important therefore to corroborate the conclusions drawn from the experimental approach by the observation of naturally occurring mutants. An analysis of the three larger LCR deletions (Fig. 1) supports the idea that HS 2-4 are necessary and that HS 1 is not sufficient for LCR activity $(24,25,27)$. The 3,030-bp HS 1 deletion seen in the father of the family described here does not segregate together with his thalassemic $\beta$ globin gene (Figs. 3 and 4) and is therefore linked to the structurally normal allele. The alternative interpretation of a change in linkage by meiotic crossover would require a recombination on two independent occasions within the $3 \mathrm{~kb}$ between the $3^{\prime}$ deletion breakpoint and the Hind II $\epsilon$ RFLP which is part of the $\beta$ haplotype. Assuming an average frequency of recombination of $0.01(1 \%)$ in $1,000 \mathrm{~kb}$ the estimated likelihood for this alternative interpretation is $9 \times 10^{-8}$.

If HS 1 were a necessary functional element of the LCR an impaired or absent function of the $\beta$ globin gene in cis would have to be expected. As the father is clinically healthy and expresses the typical hematological features of heterozygous $\beta$ thalassemia his phenotype shows that the $\beta$ globin gene in $c i s$ to the deletion is functional. It appears, therefore, that HS 1 is not required in vivo for a regulated expression of the $\beta$ globin gene in cis which corroborates the experimental evidence indicating that HS 1 is not a necessary element of the $\beta$ globin LCR. This finding may also be relevant for the development of strategies for the somatic gene therapy of the thalassemias. One of the chief obstacles to that end has been the position dependent and generally poor expression of exogenous $\beta$ globin genes in transfected cells. As outlined above, this problem can be overcome by introducing the LCR into the recombinant constructs. However, the capacity for exogeneous DNA of retroviral vectors suitable to complement the genome of bone marrow cells (10) is too low to accomodate a $\beta$ globin gene together with the 12 $\mathrm{kb}$ of the complete $\beta$ globin LCR. The analysis presented here suggests that HS 1 might be more confidently omitted from such vectors.

\section{Acknowledgments}

We are grateful to Prof. Sitzmann, Bad Homburg/Saar, Germany, for providing the patients' samples, to Dr. Smithies for making available the recombinant $5 \epsilon \mathrm{III}$, and to Prof. Kubanek for his continuous support.

This study was financially supported by the Deutsche Forschungsgemeinschaft (DFG)

\section{References}

1. Chao, M. V., P. Mellon, P. Charnay, T. Maniatis, and R. Axel. 1983. The regulated expression of $\beta$-globin genes introduced into mouse erythroleukemia cells. Cell. 32:483-493.

2. Charnay, $\mathbf{P}, \mathbf{R}$. Treisman, $\mathbf{P}$. Mellon, M. Chao, R. Axel, and T Maniatis. 1984. Differences in human $\alpha$ - and $\beta$-globin gene expression in mouse erythroleukemia cells: the role of intragenic sequences. Cell. 38:251-263.

3. Wright, S., A. Rosenthal, R. Flavell, and F. Grosveld. 1984. DNA sequences required for regulated expression of $\beta$-globin genes in murine erythroleukemia cells. Cell. 38:265-273.

4. Wright, S., E. deBoer, F. G. Grosveld, and R. A. Flavell. 1983. Regulated expression of the human $\beta$-globin gene family in murine erythroleukaemia cells. Nature (Lond.). 305:333-336.

5. Chada, K., J. Magram, K. Raphael, G. Radice, E. Lacy, and F. Costantini. 1985. Specific expression of a foreign $\beta$-globin gene in erythroid cells of transgenic mice. Nature (Lond.). 314:377-380.

6. Chada, K., J. Magram, and F. Costantini. 1986. An embryonic pattern of expression of a human fetal globin gene in transgenic mice. Nature (Lond.). 319:685-689.

7. Magram, J., K. Chada, and F. Costantini. 1985. Developmental regulation of a cloned adult $\beta$-globin gene in transgenic mice. Nature (Lond.). 315:338-340.

8. Kollias, G., N. Wrighton, J. Hurst, and F. Grosveld. 1986. Regulated expression of human ${ }^{\wedge} \gamma-, \beta$-, and hybrid $\gamma \beta$-globin genes in transgenic mice: manipulation of the developmental expression patterns. Cell. 46:89-94.

9. Townes, T. M. J. B. Lingrel, H. Y. Chen, R. L. Brinster, and R. D. Palmiter. 1985. Erythroid-specific expression of human $\beta$-globin genes in transgenic mice. EMBO (Eur. Mol. Biol. Organ.) J. 4:1715-1723.

10. Dzierzak, E. A., T. Papayannopoulou, and R. C. Mulligan. 1988. Lineagespecific expression of a human $\beta$-globin gene in murine bone marrow transplant recipients reconstituted with retrovirus-transduced stem cells. Nature (Lond.). 331:35-41.

11. Tuan, D., W. Solomon, Q. Li, and I. M. London. 1985. The " $\beta$-like- 
globin" gene domain in human erythroid cells. Proc. Natl. Acad. Sci. USA. 82:6384-6388.

12. Grosveld, F., G. Blom van Assendelft, D. R. Greaves, and G. Kollias. 1987. Position-independent, high-level expression of the human $\beta$-globin gene in transgenic mice. Cell. 51:975-985.

13. Forrester, W. C., S. Takegawa, T. Papayannopoulou, G. Stamatoyannopoulos, and M. Groudine. 1987. Evidence for a locus activation region: the formation of developmentally stable hypersensitive sites in globin expressing hybrids. Nucleic Acids Res. 16:10159-10177.

14. Tuan, D., A. Abeliovich, M. Lee-Oldham, and D. Lee. 1987. Identification of regulatory elements of human $\beta$-like globin genes. In Developmental Control of Globin Gene Expression. G. Stamatoyannopoulos and A. Nienhuis, editors. Alan R. Liss, Inc., New York. 211-220.

15. Ryan, T. M. R. R. Behringer, T. M. Townes, R. D. Palmiter, and R. L. Brinster. 1989. High-level erythroid expression of human $\alpha$-globin genes in transgenic mice. Proc. Natl. Acad. Sci. USA. 86:37-41.

16. Curtin, P. T., D. Liu, W. Liu, J. C. Chang, and Y. W. Kan. 1989. Human $\beta$-globin gene expression in transgenic mice is enhanced by a distant DNase I hypersensitive site. Proc. Natl. Acad. Sci. USA. 86:7082-7086.

17. Talbot, D., P. Collis, M. Antoniou, M. Vidal, F. Grosveld, and D. R. Greaves. 1989. A dominant control region from the human $\beta$-globin locus conferring integration site-independent gene expression. Nature (Lond.). 338:352355 .

18. Blom van Assendelft, G, O. I, Hanscombe, F. Grosveld, and D. R. Greaves. 1989. The $\beta$-globin dominant control region activates homologous and heterologous promoters in a tissue-specific manner. Cell. 56:969-977.

19. Talbot, D., S. Philipsen, P. Fraser, and F. Grosveld. 1990. Detailed analy sis of the site 3 region of the human $\beta$-globin dominant control region. EMBO (Eur. Mol. Biol. Organ.) J. 9:2169-2178.

20. Sorrentino, B., P. Ney, D. Bodine, and A. W. Nienhuis. 1990. A 46 base pair enhancer sequence within the locus activating region is required for induced expression of the gamma-globin gene during erythroid differentiation. Nucleic Acids Res. 18:2721-2731.

21. Ryan, T. M , R R Behringer, N. C Martin, T. M. Townes, R. D. Palmiter, and R. L. Brinster. 1989. A single erythroid-specific DNase I super-hypersensitive site activates high levels of human $\beta$-globin gene expression in transgenic mice. Genes Dev. 3:314-323.

22. Collis, P., M. Antoniou, and F. Grosveld. 1990. Definition of the minimal requirements within the human $\beta$-globin gene and the dominant control region for high level expression. EMBO (Eur. Mol. Biol. Organ.) J. 9:233-240.

23. Van der Ploeg L. H. T. A. Konings, M. Oort, D. Roos, L. Bernini, and R. A. Flavell. 1980. $\gamma$ - $\beta$-Thalassaemia studies showing that deletion of the $\gamma$-and $\delta$-genes influences $\beta$-globin gene expression in man. Nature (Lond.). 283:637642.

24. Vanin, E. F., P. S. Henthorn, D. Kioussis, F. Grosveld, and O. Smithies.
1983. Unexpected relationship between four large deletions in the human $\beta$-globin gene cluster. Cell. 35:701-709.

25. Curtin, P. T., and Y.W. Kan. 1988. The inactive $\beta$ globin gene on a $\gamma \delta \beta$ thalassemia chromosome has a normal structure and functions normally in vitro. Blood. 71:766-770.

26. Taramelli, R., D. Kioussis, E. Vanin, K. Bartram, J. Groffen, J. Hurst, and F. G. Grosveld. 1986. 1 and 2 are the result of a $100 \mathrm{kbp}$ deletion in the human $\beta$-globin cluster. Nucleic Acids Res. 14:7017-7029.

27. Driscoll, M. C., C. S. Dobkin, and B. P. Alter. 1989. $\gamma \delta \beta$-Thalassemia due to a de novo mutation deleting the $5^{\prime} \beta$-globin gene activation-region hypersensitive sites. Proc. Natl. Acad. Sci. USA. 86:7470-7474.

28. Abraham, E. C., A. Reese, M. Stallings, and T. H. J. Huisman. 19761977. Separation of human hemoglobins by DEAE-cellulose chromatography using glycine-KCN-NaCl developers. Hemoglobin. 1:27-44.

29. Betke, K., H. R. Marti, and I. Schlicht. 1959. Estimation of small percentages of foetal haemoglobin. Nature (Lond.). 36:1877-1878.

30. Sambrook, J., E. F. Fritsch, and T. Maniatis. 1989. Molecular Cloning. A Laboratory Manual. 2nd ed. Cold Spring Harbor Laboratory Press, Cold Spring Harbor, NY.

31. Li, Q., P. A. Powers, and O. Smithies. 1985. Nucleotide sequence of 16-kilobase pairs of DNA $5^{\prime}$ to the human $\epsilon$-globin gene. J. Biol. Chem. 260:14901-14910.

32. Orkin, S. H., H. H. Kazazian, S. E. Antonarakis, S. C. Goff, C. D. Boehm, J. P. Sexton, P. G. Waber, and P. J. V. Giardina. 1982. Linkage of $\beta$-thalassaemia mutations and $\beta$-globin gene polymorphisms with DNA polymorphisms in human $\beta$-globin gene cluster. Nature (Lond.). 296:627-631.

33. Wood, W. I., J. Gitschier, L. A. Lasky, and R. L. Lawn. 1985. Base composition independent hybridization in tetramethylammonium chloride: method for oligonucleotide screening of highly complex gene libraries. Proc. Natl. Acad. Sci. USA. 82:1585-1588.

34. Labie, D., J. Pagnier, C. Lapoumeroulie, F. Rouabhi, O Dunda-Belkhodja, P. Chardin, C. Beldjord, H. Wajchman, M. E. Fabry, and R. L. Nagel 1985. Common haplotype dependency of high ${ }^{\mathrm{G}} \boldsymbol{\gamma}$-globin gene expression and high $\mathrm{Hb} F$ levels in $\beta$-thalassemia and sickle cell anemia patients. Proc. Natl. Acad. Sci. USA. 82:2111-2114.

35. Thein, S. L., J. S. Wainscoat, M. Sampietro, J. M. Old, D. Cappellini, G. Fiorelli, B. Modell, and D. J. Weatherall. 1987. Association of thalassaemia intermedia with a beta-globin gene haplotype. Br. J. Haematol. 65:367-373.

36. Kulozik, A. E., B. C. Kar, R. K. Satapathy, B. E. Serjeant, G. R. Serjeant, and D. J. Weatherall. 1987. Fetal hemoglobin levels and $\beta^{\circ}$ globin haplotypes in an Indian population with sickle cell disease. Blood. 69:1742-1746.

37. Tsai, S.-F., D. I. K. Martin, L. I. Zon, A. D. D'Andrea, G. G. Wong, and S. H. Orkin. 1989. Cloning of cDNA for the major DNA-binding protein of the erythroid lineage through expression in mammalian cells. Nature (Lond.). 339:446-451. 